\title{
Multivariate study of Nile tilapia byproducts enriched with omega-3 and dried with different methods
}

\author{
Ana Beatriz ZANQUI ${ }^{1}$, Aloisio Henrique Pereira de SOUZA ${ }^{2,3}$, Aline Kirie GOHARA ${ }^{2}$, \\ Márcia Fernandes NISHIYAMA ${ }^{2,4}$, Ricardo Pereira RIBEIRO ${ }^{2,5}$, Nilson Evelázio de SOUZA ${ }^{1}$, \\ Jesuí Vergílio VISENTAINER ${ }^{1,2}$, Sandra Terezinha Marques GOMES $^{1}$, Makoto MATSUSHITA ${ }^{1,2 *}$
}

\begin{abstract}
The present work aimed at studying the effect of different drying methods applied to tilapia byproducts (heads, viscera and carcasses) fed with flaxseed, verifying the contents of omega-3 fatty acids. Two diets were given to the tilapia: a control and a flaxseed formulation, over the course of 60 days. After this period, they were slaughtered and their byproducts (heads, viscera and carcasses) were collected. These fish parts were analyzed in natura, lyophilized and oven dried. Byproducts from tilapia fed with flaxseed presented docosapentaenoic, eicopentaenoic and docosahexanoic fatty acids as a result of the enzymatic metabolism of the fish. The byproducts from the oven drying process had lower levels of polyunsaturated fatty acids. In the multivariate analysis, the byproducts from fish fed with flaxseed had a greater composition of fatty acids. The addition of flaxseed in fish diets, as well as the utilization of their byproducts, may become a good business strategy. Additionally, the byproducts may be dried to facilitate transport and storage.
\end{abstract}

Keywords: fatty acids; omega-3; lyophilization; principal components analysis.

Practical Applications: The present study verified a significant incorporation of omega- 3 fatty acids in Nile tilapia byproducts after 60 days of treatment using diets supplemented with flaxseed flour. This work also confirmed the high level of lipid quality of the byproducts dried using traditional oven drying and lyophilization. Diet supplementation and drying processes can be successfully applied to fish byproducts as a great marketing strategy.

\section{Introduction}

The demand for fish consumption is growing worldwide. According to the Food and Agriculture Organization (2015) report, 121, 142, 145 and 156 million tons of fish were consumed in 2007, 2008, 2009 and 2013, respectively. The fish intake was $17 \mathrm{~kg}$ per person in 2010, $18.4 \mathrm{~kg}$ in 2012 and $18.9 \mathrm{~kg}$ in 2013. This increase is directly associated with the consumption of tilapia fillet (Oreochromis niloticus), which consists of a white flesh with firm texture and mild flavor (Higuchi et al., 2013; Santos et al., 2007).

In the tilapia processing procedure, only $30 \%-40 \%$ (weight) of the fish is consumed as a fillet, and the other parts - heads, viscera, fins and bones - are discarded. However, these byproducts may be used to produce flour, pates and soups. This application minimizes the production costs (lower costs of raw material) and reduces environmental impact caused by fishery activity (Leonhardt et al., 2006; Petenuci et al., 2010).

Drying process is an alternative to extend shelf life and facilitate transportation and storage, because it can inhibit pathogenic

microorganism development and decrease biochemical reactions. The conventional drying method is oven drying due to its low cost and high production. However, the high temperatures required in this method used to deteriorate some nutrients, mainly lipids. Lyophilization is an alternative drying process that have the advantage of maintaining material structure while removing moisture at low temperature, thus increasing food stability during storage (Jesus et al., 2013; Fuchs et al., 2013a).

The lipid fraction of fish is composed of saturated and polyunsaturated fatty acids, and this profile is a result of the type of feed offered. Some studies using oil sources with high contents of alpha-linolenic fatty acid (18:3n-3) have been performed with freshwater fish, such as Nile tilapia. That fatty acid (FA) is considered strictly essential because it is the precursor of other omega-3 series fatty acids (Higuchi et al., 2013; Silva et al. 2014a). In this context, flaxseed (Linum usitatissimum, L.) is considered an oil seed ( $30 \%$ of the total lipids - TL) and an excellent source of alpha-linolenic acid (600 $\mathrm{mg}$ of FA per $\mathrm{g}$ of TL) (Sargi et al., 2013).

${ }^{1}$ Departamento de Química, Universidade Estadual de Maringa - UEM, Maringa, PR, Brazil

${ }^{2}$ Centro de Ciências Agrárias, Universidade Estadual de Maringa - UEM, Maringa, PR, Brazil

${ }^{3}$ Instituto Federal de Mato Grosso do Sul - IFMS, Coxim, MS, Brazil

${ }^{4}$ Universidade Federal da Fronteira Sul - UFFS, Realeza, PR, Brazil

${ }^{5}$ Departamento de Zootecnia, Universidade Estadual de Maringa - UEM, Maringa, PR, Brazil

*Corresponding author: mmakoto@uem.br 
This study aimed at applying multivariate tools to study Nile tilapia byproducts (heads, viscera and carcasses) dried using different methods and assess the contents of omega- 3 series fatty acids. The byproducts were obtained from fishes in captivity fed with an enriched diet and source of alpha-linolenic fatty acid (flaxseed).

\section{Material and methods}

\subsection{Experiment and sampling}

The experiment lasted 60 days and was performed in the Crow River in the city of Diamante do Norte, Parana, Brazil $\left(22^{\circ} 39^{\prime} \mathrm{S} ; 052^{\circ} 46^{\prime} \mathrm{O}\right)$. A total of 400 Nile tilapia with an initial live weight of $245 \mathrm{~g}$ were distributed in eight cages with a unit volume of $1.2 \mathrm{~m}^{3}(1.0 \times 1.0 \times 1.2 \mathrm{~m}$ high $)$ and a density of 50 fish per cage, using a completely randomized design. Each tank was considered an experimental unit, and the whole study was performed with two treatments and four replications.

Two feeds were prepared in this experiment - a control feed using soybean oil and an experimental feed where soybean oil (Treatment I) was substituted for flaxseed flour (Treatment II, $50 \mathrm{~g} \mathrm{~kg}^{-1}$ ), as shown in Table 1. The tilapia diets were isocaloric and isoproteic according to the nutritional requirements of the species (National Research Council, 1993). Feeding was done twice a day - at 9:00 and 15:00 - in a proportion equal to $2 \%$ of the biomass.

Three fish were collected per the experimental unit, starting at time zero (before starting treatment) and then again after 60 days. Then, the fish were killed using a xylocaine super dosage $\left(10 \mathrm{~g}^{-1}\right)$, before then being weighed, gutted, and filleted. The "waste" (heads, viscera and carcasses) were crushed in a multiprocessor, and were then homogenized and packed in polyethylene bags. The samples were stored in a freezer $\left(-24^{\circ} \mathrm{C}\right)$ under a nitrogen atmosphere until the analyses were performed.

\subsection{Preparation of flour}

Two drying methods were used to prepare the fish byproduct flour. First, the samples of fish carcasses, viscera and heads were pre-homogenized in a stainless steel food multiprocessor. The portion of byproduct destined for the conventional drying method was arranged in rectangular trays $(40 \times 20 \mathrm{~cm})$ and dried in a conventional oven with forced air at $105^{\circ} \mathrm{C}$ for 24 hours. The portion destined for the lyophilization method was separated in portions of approximately $150 \mathrm{~g}$, before then being arranged in $17 \mathrm{~cm}$ in diameter trays and dried using the Liotop lyophilizer (L101 model). The conditions for the pre-freezing and lyophilization drying processes were performed according to those proposed by Fuchs et al. (2013a). After the conventional and lyophilization drying processes, the samples were ground in a hammer mill to obtain a flour with a particle size of 14-16 mesh. They then were homogenized, vacuum packed in polyethylene packaging and stored at $-24{ }^{\circ} \mathrm{C}$ until analysis.

\subsection{Physical and chemical analysis}

Moisture, crude protein and ash levels were determined according to Cunniff (1998), and 6.25 was adopted as the conversion factor of total nitrogen to crude protein. Total lipids
Table 1. Control and flaxseed feeds formulations.

\begin{tabular}{lcc}
\hline \multicolumn{1}{c}{$\begin{array}{c}\text { Ingredients } \\
\left(\mathrm{g} \mathrm{kg}^{-1}\right)\end{array}$} & \multicolumn{2}{c}{ Feeds } \\
\cline { 2 - 3 } & Treatment I - Control & Treatment II - Flaxseed \\
\hline Corn & 389.60 & 408.60 \\
Soybean meal & 320.00 & 320.00 \\
Fish meal & 120.00 & 120.00 \\
Wheat bran & 80.00 & 80.00 \\
Rice flour & 50.00 & 0.00 \\
Flaxseed flour & 0.00 & 50.00 \\
Soybean oil & 19.00 & 0.00 \\
Dicalcium phosphate & 6.00 & 6.00 \\
Salt & 5.00 & 5.00 \\
Vitamin and mineral & 5.00 & 5.00 \\
supplement & & \\
Lysine & 1.20 & 1.20 \\
Propionic acid & 1.00 & 1.00 \\
Vitamin C & 0.80 & 0.80 \\
Methionine & 1.00 & 1.00 \\
Threonine & 1.00 & 1.00 \\
Tryptophan & 0.20 & 0.20 \\
BHT ${ }^{2}$ & 0.20 & 0.20 \\
\hline
\end{tabular}

${ }^{1}$ Assurance levels per kilogram of product: Vitamin A (24,000 UI); Vitamin K (30 mg); Vitamin B1 (40 mg); Vitamin B6 (35 mg); Vitamin $(80 \mathrm{mg})$; Folic acid $(12 \mathrm{mg})$; Pantothenate Calcium (100 mg); Vitamin C (600 mg); Biotin (2 mg); Cholline (1000 mg); iron (200 mg); Copper (35 mg); Manganese (100 mg); Zinc (240 mg); Iodine (1.6 mg); Cobalt $(0.8 \mathrm{mg}) .{ }^{2}$ Butil Hidroxy Toluene.

were extracted according to the methodology proposed by Bligh \& Dyer (1959).

\subsection{Fatty acid composition}

To determine the fatty acid composition, the lipids were converted into fatty acid methyl esters (FAME), according to Hartman \& Lago (1973). The FAME were separated in a gas chromatograph CP-3380 (Varian, USA) fitted with a flame ionization detector, following the conditions used by Fuchs et al. (2013b). The fatty acids were identified by the retention time methodology and were quantified using tricosanoic acid methyl ester (Sigma, USA) as an internal standard, following Joseph \& Ackman's (1992) methods. The peak areas were determined using Star 5.0 software (Varian, USA) and the concentrations were expressed in $\mathrm{mg} \mathrm{g}^{-1}$ of total lipids.

\subsection{Indices of the nutritional quality of lipids}

A better approach to the nutritional evaluation of lipids is the determination of indices based on the functional effects of fatty acid composition. These indices were the index of atherogenicity (IA) and index of thrombogenicity (IT), proposed by Ulbricht \& Southgate (1991), as well as the hypocholesterolemic/ hypercholesterolemic fatty acid ratio $(\mathrm{HH})$, proposed by Santos-Silva et al. (2002).

\subsection{Ethical aspects and biosecurity}

The Ethics Committee on Animal Use in Trials of Maringa State University, File No. 011/2011, 036/2011, approved this study. 


\subsection{Statistical analysis}

All of the analyses were done in triplicate. Principal components analysis (PCA) was applied to the sums, ratios, and indices of fatty acids (loadings). There were nine experimental conditions to be analyzed (scores): initial time - in natura (A), oven dried (B) and lyophilized (C); Treatment I - in natura (D), oven dried (E) and lyophilized (F); and Treatment II - in natura $(\mathrm{G})$, oven dried $(\mathrm{F})$ and lyophilized $(\mathrm{H})$. Averages were autoscaled so that all variables showed the same weight. In this way, PCA bidimensional graphics were obtained. All of the statistical analyses were done using the software Statsoft (2007), version 8.0 , adopting a 5\% significance level for rejection of the null hypothesis $(\mathrm{p}<0.05)$.

\section{Results and discussion}

The feed of Treatment II, containing flaxseed bran, showed a significant alpha-linolenic fatty acid content that was $578 \%$ bigger than the amount found in the feed of Treatment I.

Table 2. Physicochemical characterization and fatty acid composition of the control (Treatment I) and flaxseed bran diet (Treatment II).

\begin{tabular}{|c|c|c|}
\hline Proximal composition $^{1}(\mathrm{~g} / 100 \mathrm{~g})$ & Treatment I & Treatment II \\
\hline Moisture & $52.69 \pm 0.65$ & $52.54 \pm 0.58$ \\
\hline Crude protein & $30.13 \pm 0.47$ & $28.07 \pm 0.51$ \\
\hline Ash & $6.11 \pm 0.07$ & $7.85 \pm 0.03$ \\
\hline Total Lipids (TL) & $10.45 \pm 0.03$ & $5.37 \pm 0.24$ \\
\hline \multicolumn{3}{|l|}{ Fatty $\operatorname{acid}^{2}\left(\mathrm{mg} \mathrm{g}^{-1} \mathrm{TL}\right)$} \\
\hline 14:0 & $7.83 \pm 0.28$ & $5.13 \pm 0.12$ \\
\hline 16:0 & $155.54 \pm 5.44$ & $124.38 \pm 2.45$ \\
\hline 18:0 & $15.37 \pm 0.49$ & $10.16 \pm 0.17$ \\
\hline $16: 1 n-7$ & $37.14 \pm 1.31$ & $41.34 \pm 0.75$ \\
\hline 18:1n-9 & $295.69 \pm 9.51$ & $268.62 \pm 6.22$ \\
\hline $18: 2 \mathrm{n}-6$ (LA) & $407.96 \pm 13.29$ & $296.12 \pm 7.27$ \\
\hline $18: 3 n-3$ (LNA) & $30.67 \pm 1.00$ & $177.40 \pm 5.16$ \\
\hline \multicolumn{3}{|l|}{ Sums $\left(\mathrm{mg} \mathrm{g}^{-1} \mathrm{TL}\right)$} \\
\hline SFA & $178.74 \pm 5.47$ & $139.66 \pm 2.46$ \\
\hline MUFA & $332.83 \pm 9.60$ & $309.96 \pm 6.27$ \\
\hline PUFA & $438.63 \pm 13.33$ & $473.52 \pm 8.92$ \\
\hline$n-6: n-3$ ratio & $13.30 \pm 0.05$ & $1.67 \pm 0.04$ \\
\hline \multicolumn{3}{|c|}{$\begin{array}{l}\text { Treatment I: control diet; Treatment II: supplemented diet with flaxseed bran. LA: } \\
\text { linoleic acid; LNA: alpha-linolenic acid; SFA: total saturated fatty acids; MUFA: total } \\
\text { monounsaturated fatty acids; PUFA: total polyunsaturated fatty acids; } \mathrm{n}-6 \text { : total omega-6 } \\
\text { fatty acids; and n-3: total omega-3 fatty acids. }{ }^{1} \text { Means and standard deviation. }{ }^{2} \text { Other } \\
\text { fatty acids identified: 14:1n-9, 14:1n-7, 15:0, 16:1n-9, 16:1n-5, 17:0, 17:1n-11, 17:1n-9, } \\
\text { 17:1n-7, 18:1n-7, 18:1n-11, 18:1n-5, 20:0, 20:1n-9, 20:1n-7, 21:0, 20:2n-6, 20:3n-6, 22:0, } \\
\text { 22:4n-6, 22:5n-6, 24:0, 24:1n-9. }\end{array}$} \\
\hline
\end{tabular}

This resulted in an excellent ratio of omega- 6 by omega- 3 fatty acids. Regarding other parameters, the total lipid content of the control feed (Treatment I) was twice the content of the flaxseed diet. However, the sum of saturated, monounsaturated and polyunsaturated fatty acids did not show a considerable variation between the feeds (Table 2).

The in natura and lyophilized byproducts obtained from fish of Treatment I (control, Table 3) showed a significant increase $(\mathrm{p}<0.05)$ in the total lipid content after 60 days of treatment. The heads and carcasses from the fish fed with flaxseed (Treatment II, Table 3 ) did not show a significant variation $(\mathrm{p}<0.05)$ in any of the experimental conditions, corroborated the results of other studies (Aguiar et al., 2007; Silva et al., 2014a; Zanqui et al., 2013).

Fish byproducts from Treatments I and II (Table 4) presented higher contents of LNA in the final part of treatment (60 days). The transference of this fatty acid from the diet to the fish was 2.5 times higher in Treatment I than in II (Table 4). This effect was expected according to prior studies (Barilli et al., 2014; Carbonera et al., 2014; Higuchi et al., 2013; Nishiyama et al., 2014; Silva et al., 2014a), adding promising sources of LNA (chia, flaxseed and perilla). Another highlighted point was the increase of long and very long chain fatty acids, such as eicosapentaenoic (EPA, 20:5n-3), docosapentaenoic (DPA, 22:5n-3) and docosahexaenoic (DHA, 22:6n-3) acids. This happened due to the fish enzymatic process (elongases and desaturases), which converts LNA in these metabolites (Perini et al., 2010).

The conventional drying method (oven) may have decreased the polyunsaturated fatty acid content. It is important to highlight that the operation conditions used in this experiment did not promote the formation of trans isomers. According to Stroher et al. (2012), changes in the process and type of raw material in biscuit production were effective in a lower incidence of trans fatty acid. Some studies that added whole meal flaxseed in the formulation of food products and used higher conditions of temperature and time did not find trans fatty acid (Fuchs et al. 2013b; Pagamunici et al. 2014a; Pagamunici et al. 2014b; Souza et al., 2014; Zanqui et al., 2014).

In Treatment II, the LNA content decreased in the byproducts in natura $>$ lyophilized $>$ oven dried. The total amount of saturated fatty acid increased in the samples subjected to both drying processes - lyophilization and oven drying with forced air (Table 4).

The fatty acid composition of food is directly related to the modulation and proper functioning of the body, and this

Table 3. Physicochemical characterization of the byproducts of Nile tilapia, in natura, lyophilized and oven dried (g/100g of product).

\begin{tabular}{|c|c|c|c|c|c|c|c|c|c|}
\hline \multirow{2}{*}{ Dry basis } & \multicolumn{3}{|c|}{ In natura } & \multicolumn{3}{|c|}{ Lyophilized } & \multicolumn{3}{|c|}{ Oven dried } \\
\hline & Initial time & Treatment I & Treatment II & Initial time & Treatment I & Treatment II & Initial time & Treatment I & Treatment II \\
\hline Ash & $17.11^{\mathrm{AB}} \pm 1.74$ & $12.06^{\mathrm{B}} \pm 3.67$ & $19.62^{\mathrm{A}} \pm 2.03$ & $14.01^{\mathrm{B}} \pm 0.67$ & $13.92^{\mathrm{B}} \pm 1.37$ & $17.16^{\mathrm{A}} \pm 1.09$ & $13.81^{\mathrm{B}} \pm 0.32$ & $15.63^{\mathrm{AB}} \pm 1.14$ & $16.71^{\mathrm{A}} \pm 1.48$ \\
\hline $\begin{array}{l}\text { Crude } \\
\text { protein }\end{array}$ & $39.62^{\mathrm{A}} \pm 0.45$ & $37.37^{\mathrm{A}} \pm 2.16$ & $38.85^{\mathrm{A}} \pm 1.07$ & $41.47^{\mathrm{A}} \pm 1.35$ & $37.99^{\mathrm{A}} \pm 1.99$ & $39.32^{\mathrm{A}} \pm 2.57$ & $39.68^{\mathrm{A}} \pm 0.27$ & $36.83^{\mathrm{A}} \pm 1.42$ & $37.11^{\mathrm{A}} \pm 1.58$ \\
\hline $\begin{array}{l}\text { Total } \\
\text { lipid }\end{array}$ & $43.27^{\mathrm{B}} \pm 0.26$ & $50.58^{\mathrm{A}} \pm 1.59$ & $41.51^{B} \pm 0.11$ & $39.92^{\mathrm{B}} \pm 0.14$ & $48.09^{\mathrm{A}} \pm 2.63$ & $43.51^{B} \pm 0.95$ & $46.50^{\mathrm{A}} \pm 0.25$ & $47.54^{\mathrm{A}} \pm 1.39$ & $46.18^{\mathrm{A}} \pm 3.26$ \\
\hline
\end{tabular}

Means followed by the same letter in the same line do not present significant difference by Tukey's test ( $<<0.05)$, comparing the initial time to the Treatments I and II for the byproducts in natura, lyophilized and oven dried. 


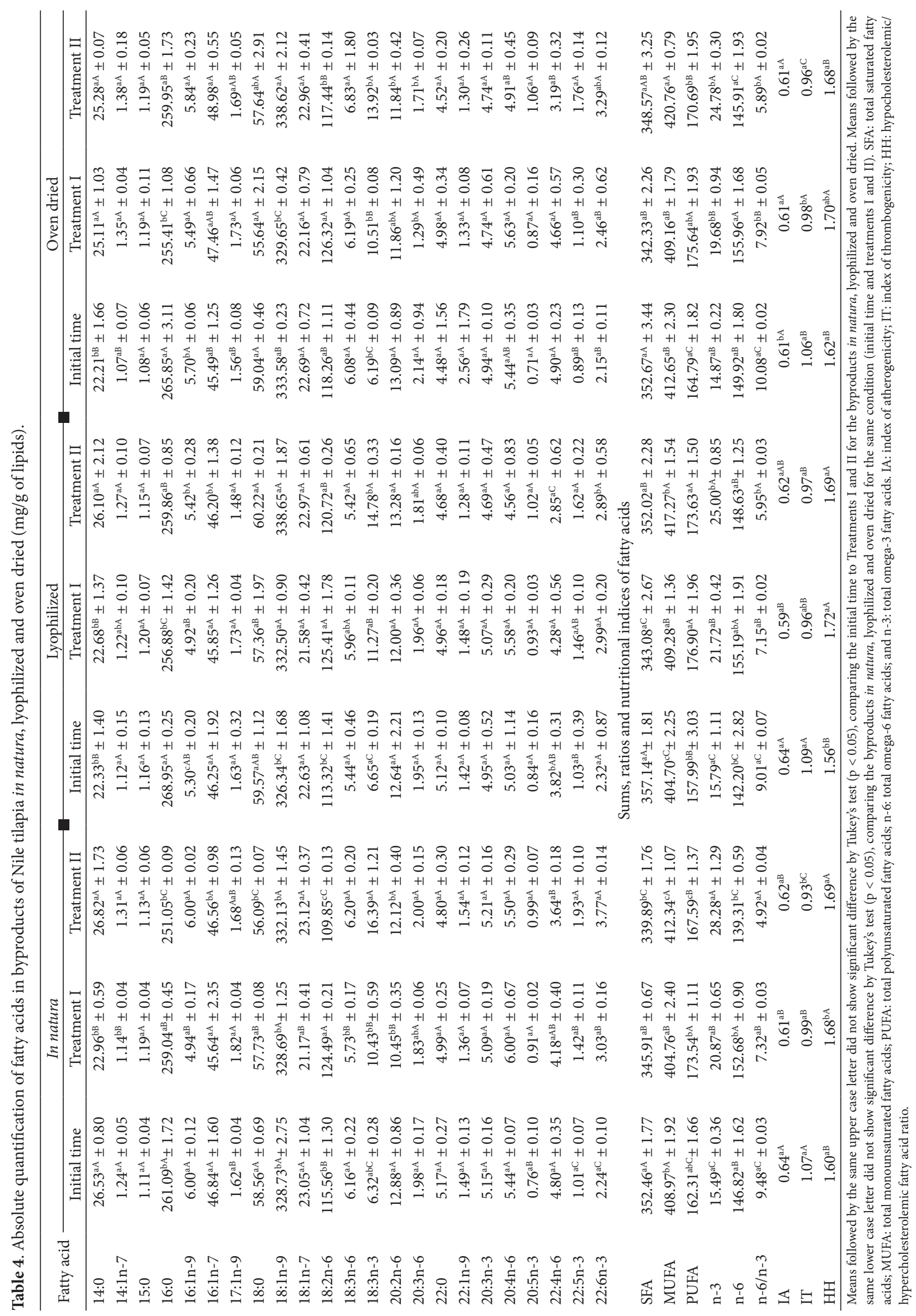




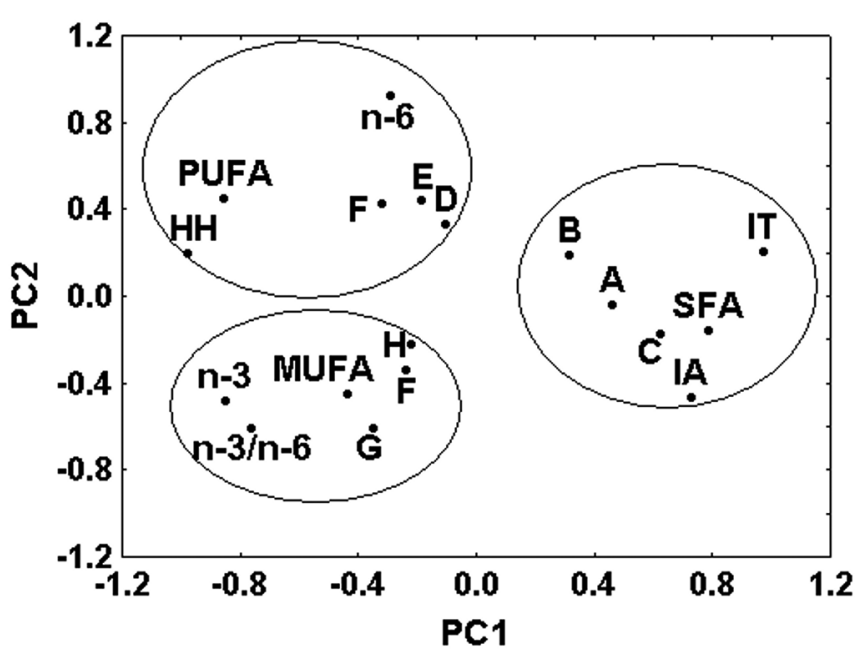

Figure 1. Principal component analysis of Nile tilapia byproducts in natura, lyophilized and oven dried. Initial time - in natura (A), oven dried (B) and lyophilized (C), Treatment I - in natura (D), oven dried (E) and lyophilized (F), Treatment II - in natura (G), oven dried (F) and lyophilized (H). SFA: total saturated fatty acids; MUFA: total monounsaturated fatty acids; PUFA: total polyunsaturated fatty acids; n-6: total omega- 6 fatty acids; and n-3: total omega-3 fatty acids. IA: index of atherogenicity; IT: index of thrombogenicity; $\mathrm{HH}$ : hypocholesterolemic/ hypercholesterolemic fatty acid ratio.

relationship can be verified considering nutritional indices (Santos-Silva et al., 2002; Ulbricht \& Southgate, 1991) and fatty acid ratios (Harwood et al., 2007; Simopoulos, 2011). The atherogenicity and thrombogenicity indices are associated with the presence of the following fatty acids: lauric (12:0), myristic (14:0), palmitic (16:0) and stearic (18:0). The higher content of these saturated fatty acids and the lower proportion of mono and polyunsaturated fatty acids may increase the incidence of coronary disease. In this study, the values of IA and IT (Table 4) were higher than were the ones reported by Souza et al. (2015), Silva et al. (2014b), and Fuchs et al. (2013a), who used flaxseed flour in the products.

The byproducts from Treatments I and II presented higher ratios of $\mathrm{HH}$ in all of the evaluated conditions (Table 4). This ratio is indicative of the hypocholesterolemic effect, which is related to a lower risk of cardiovascular diseases (Ratnayake \& Galli, 2009). According to Simopoulos (2011), the excessive consumption of lipids, trans fatty acids and an unbalanced n-6:n-3 ratio are related to a higher frequency of myocardial infarction cases, hypercholesterolemia, increased low density lipoprotein (LDL) cholesterol and blood pressure, atheroma, lipid disorders and other diseases. The n-6:n-3 ratio of Treatment II was the best value (1:4) because it was close to the ideal value of 1:1 (Ratnayake \& Galli, 2009).

The principal components analysis was applied to verify the fatty acid composition data of the Nile tilapia byproducts. The principal components $\mathrm{PC} 1$ and $\mathrm{PC} 2$ in the two-dimensional graphic (Figure 1) were selected according to their statistical significance $(\mathrm{p}<0.05)$ and they explained $42.45 \%$ and $20.27 \%$ of data variance, respectively. The byproduct samples in the initial time (in natura, lyophilized and oven dried) presented a high contribution of IT, IA and SFA in PC1. The control treatment (I, Table 1) in the evaluated conditions showed positive contribution in PC2 and was characterized by $\mathrm{n}-6, \mathrm{HH}$ and PUFA loadings. The in natura, lyophilized and oven dried samples of treatment with flaxseed flour (II, Table 2) were separated in the left lower quadrant (PC2, PC2) due to the MUFA and n-3 content, and the n-3/n-6 ratio in Figure 1. This last sample presented the best fatty acid composition (Table 4).

\section{Conclusions}

The diet supplementation of Nile tilapia with flaxseed flour as a source of alpha-linolenic fatty acid was promising and improved the fatty acid composition of the byproducts. The oven drying process resulted in a lower ratio of polyunsaturated to saturated fatty acids. Both drying process (traditional oven and lyophilization) showed higher saturated fatty acid contents than did the in natura byproducts for the same treatment (control and flaxseed). In the multivariate analysis, the in natura, lyophilized and oven dried byproducts from flaxseed treatment presented the best fatty acid composition. In this context, the addition of flaxseed flour in Nile tilapia feeding was considered a great business strategy to improve the quality of food. In addition, the use of fish byproducts to produce food is very promising to reduce fishery residues and costs. The drying process is very important to facilitate transportation and storage of food, improving market availability.

\section{References}

Aguiar, A. C., Morais, D. R., Santos, L. P., Stevanato, F. B., Visentainer, J. E. L., Souza, N. E., \& Visentainer, J. V. (2007). Effect of flaxseed oil in diet on fatty acid composition in the liver of Nile tilapia (Oreochromis niloticus). Archivos Latinoamericanos de Nutricion, 57(3), 273-277. PMid:18271406.

Barilli, D. J., Santarosa, M., Zanqui, A. B., Boscolo, W. R., Feiden, A., Furuya, W. M., Gomes, S. T. M., Visentainer, J. V., Souza, N. E., \& Matsushita, M. (2014). Incorporation of conjugated linoleic acid (CLA) and $\alpha$-linolenic acid (LNA) in pacu fillets. Food Science and Technology (Campinas.), 34(1), 74-81. http://dx.doi.org/10.1590/ S0101-20612014005000010.

Bligh, E. G., \& Dyer, W. J. (1959). A rapid method of total lipid extraction and purification. Canadian Journal of Biochemistry and Physiology, 37(8), 911-917. http://dx.doi.org/10.1139/o59-099. PMid:13671378.

Carbonera, F., Bonafe, E. G., Martin, C. A., Montanher, P. F., Ribeiro, R. P., Figueiredo, L. C., Almeida, V. C., \& Visentainer, J. V. (2014). Effect of dietary replacement of sunflower oil with perilla oil on the absolute fatty acid composition in Nile tilapia (GIFT). Food Chemistry, 148(1), 230-234. http://dx.doi.org/10.1016/j.foodchem.2013.10.038. PMid:24262550.

Cunniff, P. A. (1998). Official methods of analysis of Association of Official Analytical Chemistry International (16th ed.). Arlington: AOAC.

Food and Agriculture Organization - FAO. (2015). Yearbook of fishery statistics summary tables. World apparent consumption by continent. Retrieved from http://www.fao.org/fishery/statistics/en.

Fuchs, R. H. B., Ribeiro, R. P., Bona, E., \& Matsushita, M. (2013a). Development of a freeze-dried misture of Nile tilapia (Oreochromis niloticus) croquette using a GA-based multiobjective optimization. Journal of the Science of Food and Agriculture, 93(5), 1042-1048. http://dx.doi.org/10.1002/jsfa.5844. PMid:22936598. 
Fuchs, R. H. B., Ribeiro, R. P., Matsushita, M., Tanamati, A. A. C., Bona, E., \& Souza, A. H. P. (2013b). Enhancement of the nutritional status of Nile tilapia (Oreochromis niloticus) croquettes by adding flaxseed flour. LWT -. Food Science and Technology (Campinas.), 54(2), 440-446.

Hartman, L., \& Lago, R. C. A. (1973). Rapid preparations of fatty acid methyl esters from lipids. Laboratory Practice, 22(6), 475-477. PMid:4727126.

Harwood, J. L., Evans, M., Ramji, D. P., Murphy, D. J., \& Dodds, P. F. (2007). Medical and agricultural aspects of lipids. In J. L. Harwood, F. D. Gunstone, \& A. J. Dijkstra (Eds.), The lipid handbook (Chap. 11, pp. 703-756). New York: CRC Press.

Higuchi, L. H., Feiden, A., Matsushita, M., Santarosa, M., Zanqui, A. B., Bittencourt, F., \& Boscolo, W. R. (2013). Quantification of fatty acids in tilápia fingerlings (Oreochromis niloticus) fed with different sources of vegetable oils. Semina: Ciências Agrárias, 34(4), 1913-1924.

Jesus, M. N., Zanqui, A. B., Valderrama, P., Tanamati, A., Maruyama, S. A., Souza, N. E., \& Matsushita, M. (2013). Sensory and physicochemical characteristics of desserts prepared with egg products processed by freeze and spray drying. Food Science and Technology (Campinas.), 33(3), 549-554. http://dx.doi.org/10.1590/S010120612013005000083.

Joseph, J. D., \& Ackman, R. (1992). Capillary column gas chromatographic method for analysis of encapsulated fish oils and fish oil ethyl esters: collaborative study. Journal of the American Oil Chemists' Society, 75(3), 488-506.

Leonhardt, J. H., Caetano-Filho, M., Frossard, H., \& Moreno, A. M. (2006). Morphometrics, fillet yield and fillet composition in Nile tilapia, Oreochromics niloticus, strains thai chitralada, Brazil local and their hybrid. Semina: Ciências Agrárias, 27(1), 125-132.

National Research Council - NRC. (1993). Nutrient requirements of fish. Washington, National Academy Press.

Nishiyama, M. F., Souza, A. H. P., Gohara, A. K., Santos, H. M. C., Oliveira, C. A. L., Ribeiro, R. P., Souza, N. E., Gomes, S. T. M., \& Matsushita, M. (2014). Chemometrics applied to the incorporation of omega-3 in tilápia fillet feed flaxseed flor. Food Science and Technology (Campinas.), 34(3), 449-455. http://dx.doi.org/10.1590/1678-457x.6341.

Pagamunici, L. M., Gohara, A. K., Souza, A. H. P., Bittencourt, P. R. S., Torquato, A. S., Batiston, W., Gomes, S. T. M., Souza, N. E., Visentainer, J. V., \& Matsushita, M. (2014a). Using chemometric techniques to chatacterize gluten-free cookies containing the whole flour of a new quinoa cultivar. Journal of the Brazilian Chemical Society, 25(2), 219-228.

Pagamunici, L. M., Souza, A. H. P., Gohara, A. K., Silvestre, A. A. F., Visentainer, J. V., Souza, N. E., Gomes, S. T. M., \& Matsushita, M. (2014b). Multivariate study and regression analysis of gluten-free granola. Food Science and Technology (Campinas.), 34(1), 127-134. http://dx.doi.org/10.1590/S0101-20612014005000005.

Perini, J. A. L., Stevanato, F. B., Sargi, S. C., Visentainer, J. E. L., Dalailo, M. M. O., Matsushita, M., Souza, N. E., \& Visentainer, J. V. (2010). Omega-3 and omega-6 polyunsaturated fatty acids: metabolism in mammals and immune response. Revista de Nutrição, 23(6), 1075-1086. http://dx.doi.org/10.1590/S1415-52732010000600013.

Petenuci, M. E., Stevanato, F. B., Morais, D. R., Santos, L. P., Souza, N. E., \& Visentainer, J. V. (2010). Composition and lipid stability of tilapia fishbone flour. Ciência e Agrotecnologia, 34(5), 1279-1284. http://dx.doi.org/10.1590/S1413-70542010000500028.

Ratnayake, W. M., \& Galli, C. (2009). Fat and fatty acid terminology, methods of analysis and fat digestion and metabolism: A background review paper. Annals of Nutrition \& Metabolism, 55(1-3), 8-43. http:// dx.doi.org/10.1159/000228994. PMid:19752534.
Santos, L. D., Zara, R. F., Visentainer, J. V., Matsushita, M., Souza, N. E., \& Franco, M. L. R. S. (2007). Sensory evaluation and yield of Tilapia (Oreochromis niloticus) smoked fillets in rosemary (Rosmarinus officinalis) presence. Ciência e Agrotecnologia, 32(2), 406-412. http:// dx.doi.org/10.1590/S1413-70542007000200021.

Santos-Silva, J., Bessa, R. J. B., \& Santos-Silva, F. (2002). Effect of genotype, feeding system and slaughter weigt on the quality of light lambs. II. Fatty acid composition of meat. Livestock Production Science, 77(2-3), 187-194. http://dx.doi.org/10.1016/S0301-6226(02)00059-3.

Sargi, S. C., Silva, B. C., Santos, H. M. C., Montanher, P. F., Boeing, J. S., Santos-Júnior, O. O., Souza, N. E., \& Visentainer, J. V. (2013). Antioxidant capacity and chemical composition in seeds rich in Omega-3: chia, flax, and perilla. Food Science and Technology (Campinas.), 33(3), 541-548. http://dx.doi.org/10.1590/S010120612013005000057.

Silva, B. C., Santos, H. M. C., Montanher, P. F., Boeing, J. S., Almeida, V. C., \& Visentainer, J. V. (2014a). Incorporation of Omega-3 fatty acids in Nile tilapia (Oreochromis niloticus) fed chia (Chia hispanica L.) bran. Journal of the American Oil Chemists' Society, 91(1), 429437. http://dx.doi.org/10.1007/s11746-013-2391-0.

Silva, C. M., Zanqui, A. B., Souza, A. H. P., Gohara, A. K., Chaves, M. A., Gomes, S. T. M., Cardozo-Filho, L., Souza, N. E., \& Matsushita, M. (2014b). Chemometric study of Perilla acids from subcritical n-propane extracted oil. Journal of the Chemical Society, 26(1), 14-21.

Simopoulos, A. (2011). Evolutionary aspects of diet: the omega-6/ omega-3 ratio and the brain. Molecular Neurobiology, 44(2), 203215. http://dx.doi.org/10.1007/s12035-010-8162-0. PMid:21279554.

Souza, A. H. P., Gohara, A. K., Pagamunici, L. M., Visentainer, J. V., Souza, N. E., \& Matsushita, M. (2014). Development, characterization and chemometric analysis of gluten-free granolas containing whole flour of pseudo-cereals new cultivars. Acta Scientiarum. Technology, 36(1), 157-163. http://dx.doi.org/10.4025/19195.

Souza, A. H. P., Gohara, A. K., Rotta, E. M., Chaves, M. A., Silva, C. M., Dias, L. F., Gomes, S. T. M., Souza, N. E., \& Matsushita, M. (2015). Effect of the addition of chia's by-product on the composition of fatty acids in hamburgers through chemometric methods. Journal of the Science of Food and Agriculture, 95(5), 928-935. http://dx.doi. org/10.1002/jsfa.6764. PMid:24909559.

Statsoft. (2007). Statistica: data analysis software system. Version 8.0. Tulsa: Statsoft.

Stroher, G. L., Rodrigues, A. C., Gohara, A. K., Visentainer, J. V., Matsushita, M., \& Souza, N. E. (2012). Fatty acid quantification in different types of cookies with emphasis on trans fatty acids. Acta Scientiarum. Technology, 34(1), 105-110. http://dx.doi.org/10.4025/ actascitechnol.v34i1.10304.

Ulbricht, T. L. V., \& Southgate, D. A. T. (1991). Coronary heart disease: seven dietary factors. Lancet, 338(8773), 985-992. http://dx.doi. org/10.1016/0140-6736(91)91846-M. PMid:1681350.

Zanqui, A. B., Bastiani, D., Souza, A. H. P., Marques, D. R., Gohara, A. K., Matsushita, M., \& Monteiro, A. R. G. (2014). Developing of mini panettone containing omega-3 in partial substitution of wheat flour for golden linseed flour (Linum usitatissimum L.). Revista Virtual de Química, 6(4), 968-976.

Zanqui, A. B., Maruyama, S. A., Barilli, D. J., Ribeiro, S. A. O., Gomes, S. T. M., Visentainer, J. V., Souza, N. E., Boscolo, W. R., \& Matsushita, M. (2013). Incorporation of conjugated linoleice and alpha linolenic fatty acid into Pimedolus maculatus fillets. Food Science and Technology (Campinas.), 33(3), 532-540. http://dx.doi.org/10.1590/ S0101-20612013005000066. 